\title{
Child Social Welfare Institution Participation in the Implementation of Good Governance
}

\author{
Muhammad Rais Rahmat Razak ${ }^{12 *}$, Akhwan Ali ${ }^{12}$ \\ ${ }^{1}$ Universitas Muhammadiyah Sidenreng Rappang \\ ${ }^{2}$ Postgraduate Program of Public Administration, Universitas negeri Makassar. \\ Email:mraisrahmat@gmail.com¹, alitribun@gmail.com²
}

(Received: September 1-2019; revised: October 20-2019; published: December 31-2019)

\begin{abstract}
The application of the principles of good governance is not only limited to ministries and government agencies or central and regional government levels. The application of good governance needs to be extended to non-governmental social institutions such as children's social welfare institutions. Sejati Orphanage of Muhammadiyah Rappang is one of the social welfare institutions of children in South Sulawesi, founded by H. ismail Ambo Mariama since 1950 as a form of social concern for the massacre known as the 40,000 victims in December 1949 in South Sulawesi. This research aims to determine the level of participation and application of the principles of good governance in the orphanage. This research uses quantitative descriptive method by describing the two variables using the Likert scale and examining the relationship between the two variables using linear regression analysis. Samples is 30 was taken from 150 populations. The results show that the level of participation and application of the principles of good governance are included in the excellent category. While the level of participation influences 42.2 percent of the application of the principles of good governance. This shows that the application of the principles of good governance in social institutions is easier compared to other institutions.
\end{abstract}

Keywords: good governance; Muhammadiyah; orphanages; participation; social

\section{INTRODUCTION}

The 1945 Constitution article 34 paragraph 1 states that "the poor and abandoned children are nurtured by the State". So that the State is obliged to provide guidance to LKSA (Child Social Welfare Institution) which is a social institution formed by the community based on Social Minister Regulation No. 30 / HUK / 2011 concerning National Standard of Care for Child Welfare Institutions (LKSA). Changing the name of the Orphanage to LKSA does not mean that the state has created a new institution but one of the government's efforts to improve governance in the field of social welfare.

So that it can cause paradigm changes in its management. Data from the 2016 National Socio-Economic Survey (Susenas), shows that in Indonesia there are 11 million children living in households with only the heads of grandparents. Meanwhile, data from the Ministry of Social Affairs Directorate of Children states, there are around 250 thousand children living in more than 6,161 LKSAs throughout Indonesia.(Fizriyani, 2017).

Based on the foregoing it becomes important and urgent for the government to ensure good management of non-governmental institutions especially those engaged in the social 
346 Jurnal Ilmiah Ilmu Administrasi Publik: Jurnal Pemikiran dan Penelitian Administrasi Publik Volume 9 Number 2, July- December 2019. Page 345-354

welfare of children. So that the management and fostering pattern of foster children who are state children can be in line with the implementation of good governance by the government.

The researcher made preliminary observations of one of the LKSAs in Sidenreng Rappang Regency, namely LKSA Sejati Orphanage of Muhammadiyah Rappang in June 2018 and several things that were discovered and caught by researchers, namely: 1) In the last 2 years, an increase in the number of foster children is more than 50 percent, 2) From the number of 60 children in 2016 to 105 children in 2018,3) Public interest is quite high amid the economic progress of the family to entrust their children or family in the LKSA Sejati Orphanage of Muhammadiyah Rappang, is an interesting problem to study.

Are there governance principles in its management. There are assistants, caregivers and administrators who manage and they work according to their respective Job Descriptions. There is always a song that is used, namely, IB3 (Worship, Learning, Practicing and Working) and is an encouragement and director in coaching children. The above conditions then become material for researchers, whether the LKSA Sejati Orphanage of Muhammadiyah Rappang as a non-governmental social organization has implemented the Principles of Good Governance in its Management.

\section{METHOD}

The research method used is Quantitative Research and as an initial step in designing a research design is a plan or strategy that is used to answer research problems (test hypotheses) and control variables or focus of research, can also be understood as a plan and structure of inquiry used to obtain evidence empirical in answering research questions (Ahmad, 2015). This research takes locus of LKSA Sejati Orphanage of Muhammadiyah Rappang and the time of the study since the observation of preliminary observations to be published in accredited scientific journals is one year. This research is included in institutional research which according to Sugiyono is aimed at getting information that can be used to develop institutions.(Sugiyono, 2017). With the use of Quantitative Research, it can be seen the level of explanation, which according to David Kline (level of explanation) in Sugiyono (20017: 11) is the level of explanation or level of explanation that intends to explain the position of the variables studied and the relationship between one variable with another variable .

The variables in this study consisted of two descriptive variables, namely LKSA Participation and Application of Governance Principles. And equipped with associative variables, namely how the relationship between LKSA participation and the application of the principles of good governance. As an initial hypothesis that the better the participation of LKSA Sejati Orphanage of Muhammadiyah Rappang will further enhance the application of good governance principles. To conduct this research, the population is used according to Purwanto (2017: 37) is all individuals / units that are the target of the study while the sample is part of the population selected following certain procedures so that it can represent the population

(Purwanto, 2017) Jumlah populasi yang digunakan adalah 145 orang terdiri dari jumlah anakasuh 105 orang, pendamping/pengasuh 15 orang dan Pengurus Yayasan 25. Kemudian Teknik sampling yang digunakan adalah Proportionate Stratified Random Sampling, teknik ini digunakan jika karakteristik setiap unsur populasi heterogen namun bersifat secara proporsional 
(Purwanto, 2017). The method used in determining the sample is to use the formula, $\mathrm{x} / \mathrm{y}$ multiplied by ' $n$ ' where ' $x$ ' is the target number of samples; ' $y$ ' is the number of population and ' $n$ ' is the population of each stratum. In this case, the LKSA Sejati Orphanage of Muhammadiyah Rappang consists of 3 important components that have different roles and responsibilities so a sample that is representative of the population is needed.

The desired number of samples is 30 , then the proportional distribution of each stratum is. Sampling from foster children of 21.7 or rounding 22 is taken from the calculation (30/145)* 105. Sampling from a companion / caregiver is 3 , taken from $(30 / 145) * 15$. Sampling of foundation administrators is 5 , taken from $(30 / 145) * 25$. The data is then processed into a frequency table with a Likert scale to give weight to the results of the study. The results of the frequency table management will give a description of the condition of two descriptive variables, namely LKSA participation and the application of the principles of good governance. Meanwhile, to find out the associative variable or whether there is a relationship between the "X" and "Y" variables, a Simple Linear Regression Analysis can be used using SPSS version 20.00 .

To maintain data quality, a validity test is performed to ascertain whether the data from the field is valid data and nothing is missing. The test uses the "Product moment Pearson correlation" method of each question item questionnaire with the help of SPS version 20. If ' $r$ ' count is greater than ' $r$ table', then it is declared valid. Meanwhile, to ensure data consistency, a reliability test was used by comparing Cronbach's alpha with the ' $r$ table'. If Cronbach's alpha is greater than ' $r$ table', then it is declared reliable.

\section{RESULT AND DISCUSSION}

\section{Validity}

Analysis of the validity of the Participation variable (X) and the Principles of good governance (Y), by comparing the value of $r$ table 0.3061 (at $\mathrm{df} 28$ with a significance of 0.05 ), so that a validity recapitulation of table 1 is obtained.

\section{Table 1}

Recapitulation of the validity of variables $X$ and $Y$

\begin{tabular}{cllcccc}
\hline Item & X-r count & Y-r count & Comparison & r tabel & Remark & status \\
\hline item_1 & 0.734 & 0.524 & $>$ & 0.3061 & Is more & valid \\
item_2 & 0.752 & 0.543 & $>$ & 0.3061 & Is more & valid \\
item_3 & 0.677 & 0.336 & $>$ & 0.3061 & Is more & valid \\
item_4 & 0.564 & 0.392 & $>$ & 0.3061 & Is more & valid \\
item_5 & 0.639 & 0.307 & $>$ & 0.3061 & Is more & valid \\
item_6 & 0.473 & 0.61 & $>$ & 0.3061 & Is more & valid \\
item_7 & 0.362 & 0.675 & $>$ & 0.3061 & Is more & valid \\
item_8 & 0.586 & 0.468 & $>$ & 0.3061 & Is more & valid \\
item_9 & 0.443 & 0.618 & $>$ & 0.3061 & Is more & valid \\
Item_10 & - & 0.5 & $>$ & 0.3061 & Is more & valid \\
\hline
\end{tabular}

(Source: spss results ver. 20., 2019) 
348 Jurnal Ilmiah Ilmu Administrasi Publik: Jurnal Pemikiran dan Penelitian Administrasi Publik Volume 9 Number 2, July- December 2019. Page 345-354

The results of the validity test show that, 9 items on the " $\mathrm{X}$ " variable and 10 items on the "Y" variable are valid.

\section{Reliability Test}

Reliability analysis on the Participation variable $(\mathrm{X})$ and the principles of good governance $(\mathrm{Y})$, by comparing alpha cronbach with $r$ table value of 0.3061 (at df 28 with a significance of 0.05 ), so the reliability recapitulation is obtained as follows:

\section{Table 2}

Recapitulation of $\mathrm{X}$ and $\mathrm{Y}$ variable reliability

\begin{tabular}{rllclll}
\hline Item & $\begin{array}{c}\text { X-alpha } \\
\text { cronbach }\end{array}$ & $\begin{array}{c}\text { Y-alpha } \\
\text { cronbach }\end{array}$ & Comparison & r tabel & Remark & status \\
\hline item_1 & 0.695 & 0.692 & $>$ & 0.3061 & Is more & reliabel \\
item_2 & 0.694 & 0.692 & $>$ & 0.3061 & Is more & reliabel \\
item_3 & 0.72 & 0.708 & $>$ & 0.3061 & Is more & reliabel \\
item_4 & 0.72 & 0.704 & $>$ & 0.3061 & Is more & reliabel \\
item_5 & 0.724 & 0.711 & $>$ & 0.3061 & Is more & reliabel \\
item_6 & 0.735 & 0.682 & $>$ & 0.3061 & Is more & reliabel \\
item_7 & 0.736 & 0.669 & $>$ & 0.3061 & Is more & reliabel \\
item_8 & 0.716 & 0.699 & $>$ & 0.3061 & Is more & reliabel \\
item_9 & 0.736 & 0.687 & $>$ & 0.3061 & Is more & reliabel \\
Item_10 & - & 0.702 & $>$ & 0.3061 & Is more & reliabel \\
\hline
\end{tabular}

(Source: spss results ver. 20., 2019)

The data obtained, that the question items used at the level of participation and the application of the principles of good governance can be declared reliable.

\section{Frequency Analysis}

The formula used to analyze data using frequency tabulation techniques, namely:

Information:

$\mathrm{P}=$ Percentage Results

$\mathrm{F}=$ Number of Frequency of Respondents

$\mathrm{n}=$ Number of Samples

Range:

Score $=$ Frequency $\mathrm{x}$ Weight 
To describe the classification of percentages from the calculation results, the table Sugiyono (2016: 110) has been processed as in table 3.

\section{Table 3}

\begin{tabular}{cll}
\multicolumn{2}{c}{ Research Results Category } \\
\hline No. & \multicolumn{1}{c}{ Category } & \multicolumn{1}{c}{ Range } \\
\hline 1. & Very good & $81 \%-100 \%$ \\
2. & Good & $61 \%-80 \%$ \\
3. & Poor & $41 \%-60 \%$ \\
4. & Bad & $21 \%-40 \%$ \\
5. & Is not very good & $0 \%-20 \%$ \\
\hline
\end{tabular}

\section{Participation $(\mathbf{X})$}

With a frequency table analysis, a recapitulation of the average percentage of research results obtained for each indicator in table 4 is obtained.

\section{Table 4}

Summary of participation variable $(\mathbf{X})$

\begin{tabular}{llc}
\hline No. & Indicator & Persentase ( \%) \\
\hline 1 & Planning & 85 \\
2 & Implementation & 87 \\
3 & Enjoying result & 81 \\
4 & Evaluation & 89 \\
\hline Average Percentage (\%) & $\mathbf{8 5 . 5}$ \\
\hline
\end{tabular}

(Source: spss results ver. 20., 2019)

Respondents' perceptions about the level of participation of LKSA Sejati Orphanage of Muhammadiyah Rappang showed an average value of 85.5 percent included in the very good category. Of the 4 indicators of participation, the evaluation has the highest percentage level of 89 percent followed by the participation of the implementation of 87 percent then planning participation 85 percent then participation enjoys the results of 81 percent. This shows that in the management of LKSA have a very good level of participation. This conclusion is strengthened by the opinion of Drs. Samsu Tang, S.Pd. M.Pd. Deputy Chairman of the Muhammadiyah Regional Chair Sidenreng Rappang in an interview conducted in early July 2019:

"The management of this orphanage provides an excellent example to the community, where children are well educated and fostered. Taught by modern plantation skills, speech skills through muhadarah every Saturday night and Saturday night I often monitor from the outside because the loudspeakers are directed to the community. And the community is happy because it can monitor directly. The community is also happy because there are not many children in the orphanage, when 
350 Jurnal Ilmiah Ilmu Administrasi Publik: Jurnal Pemikiran dan Penelitian Administrasi Publik

Volume 9 Number 2, July- December 2019. Page 345-354

they leave the complex there is a red exit permit. they have a planned activity and there is always an evaluation 3 times a week that the morning prayer by the management. Every month there is a face-to-face meeting and heart-to-heart talk as well as evaluation and direction from the leadership to the management personnel. Likewise every 27 Ramadan there is an annual evaluation of students and managers and the awarding is carried out in front of children and managers. Yes, I am also the Chairperson of PDM who is in charge of social organizations, because everything has gone very well. This activity has been going on for several years, so that something like this can be maintained. So in the future there needs to be a product in the form of standard procedures or we usually hear with SOP ".

The results of the interview with Syamsu Tang further reinforced that, LKSA Sejati Orphanage of Muhammadiyah Rappang has a very good level of participation. And far better when compared with community participation in mountainous areas towards the application of the principles of good governance which is only 69.2 percent. (Razak, M.R.R;Harfiah, 2018),

\section{Application of Good Governance principles (Y)}

To find out how the variable "Y" or the level of application of the principles of good governance in which there are indicators of accountability, transparency, openness and legal rules can be known by calculating the average value of the indicator as illustrated in table 5 .

\section{Table 5}

Recapitulation of variables applying the principles of good governance

\begin{tabular}{clc}
\hline No. & \multicolumn{1}{c}{ Indicator } & Percentage ( \%) \\
\hline 1 & Accountability & 88 \\
2 & Transparency & 87 \\
3 & Openness & 88 \\
4 & Legal rules & 97 \\
\hline Aveage percentage (\%) & 90 \\
\hline
\end{tabular}

(Source: SPSS results ver. 20. 20. 2019)

Respondents' perceptions about the level of application of the principles of good governance showed an average value of 90 percent included in the excellent category. Of the 4 indicators of the principles of good governance, the rule of law has the highest level of application which is 97 percent followed by accountability and 88 percent disclosure then the application of 87 percent transparency. The recapitulation data shows that the four principles of good governance examined, showed that all of them were included in the excellent category. This is confirmed by the results of researchers' interviews with Drs. Syamsu Tang. Deputy Chairman of PDM Sidenreng Rappang in early July 2019, that:

This orphanage applies the principles of good governance, there is such a thing as transparency, openness and legal rules. The management of this orphanage, seems to be serious and maintain the mandate well, even though the management is very good, just how this can be a system that if 
the manager is now inactive can be passed on by others. So it may be necessary to make some work standards or guidelines that can be a guide in carrying out various activities. Now there are standard rules, but more needs to be made. So that the management of this institution is run by a standard system or procedure.

\section{Simple Linear Regression Analysis}

To answer the formulation of the associative problem, namely how the influence of the LKSA participation variable of the Sejati orphanage of Muhammadiyah Rappang in applying the principles of good governance, can use simple linear regression analysis with the following general equations:

$$
\mathrm{Y}=\mathrm{bo}+\mathrm{b} . \mathrm{X}
$$

Where:

$\mathrm{Y}$, is the variable Implementation of the principles of good governance

bo, constant

$\mathrm{b}$, is the regression coefficient

$\mathrm{X}$, is the participatory variable of LKSA Sejati Orphanage of Muhammadiyah Rappang. The "b" coefficient is called the regression direction coefficient and states the average change in the variable " $Y$ " for each change in the variable " $\mathrm{X}$ " by one unit. This change is an increase if, " $b$ " is positive while there will be a decrease if " $b$ " is negative. By using SPSS version 20.00 data processing, the output table coefficient data is obtained in table 6 .

\section{Table 6}

\section{Coefficients Table}

\begin{tabular}{llllll}
\hline Model & \multicolumn{2}{l}{$\begin{array}{l}\text { Unstandardized } \\
\text { Coefficients }\end{array}$} & $\begin{array}{l}\text { Standardized } \\
\text { Coefficients }\end{array}$ & & \multirow{2}{*}{ Sig. } \\
\cline { 2 - 4 } & $\mathrm{B}$ & Std. Error & Beta & & \\
\hline (Constant) & 26.431 & 4.187 & & 6.312 & .000 \\
Partisipasi LKSA & .467 & .109 & .631 & 4.304 & .000 \\
\hline
\end{tabular}

a. Dependent Variable: Penerapan Prinsip Good Governance

(Source: SPSS results ver. 20. 20. 2019)

By substituting these numbers a simple linear regression equation is obtained as follows:

$$
\mathrm{Y}=2.553+0.444 \mathrm{X}
$$

This shows that;

a. A constant of 2.553 states that, if the value of LKSA participation is zero or absent, the value of applying good governance principles will remain at 2,553.

b. The regression coefficient $\mathrm{X}$ of 0.444 states that for each addition of one unit of LKSA participation value, the value of applying good governance principles will increase by 0.444 .

Based on table 6 above, known $\mathrm{t}$ value $=6.312>\mathrm{t}$ table $=0.683$ with a significance of $0,000<0.05$. This shows that, Ho is rejected and H1 is accepted, so that the criteria will apply, 
352 Jurnal Ilmiah Ilmu Administrasi Publik: Jurnal Pemikiran dan Penelitian Administrasi Publik Volume 9 Number 2, July- December 2019. Page 345-354

that there is a very real / significant influence between the LKSA (X) participation variable on the variable implementation of the principles of good governance (Y).

To find out how much influence the participation variable $(X)$ has on the implementation of good governance $(\mathrm{Y})$ variables, it can be seen how much the value $\mathrm{r} 2$ or $\mathrm{r}$ square in the Model summary table.

Table 7

Model Summary Table

\begin{tabular}{lllll}
\hline Model & $\mathrm{R}$ & R Square & $\begin{array}{l}\text { Adjusted } \\
\text { Square }\end{array}$ & $\begin{array}{c}\text { R Std. Error of } \\
\text { the Estimate }\end{array}$ \\
\hline 1 & $.649^{\mathrm{a}}$ & .422 & .401 & .20480 \\
\hline
\end{tabular}

a. Predictors: (Constant), Partisipasi LKSA

(Source: SPSS results ver. 20. 20. 2019)

$\mathrm{R}$ square value is 0.422 , indicating that the participation variable $(\mathrm{X})$ has a $42.2 \%$ influence on the application of the principles of good governance, while $57.8 \%$ is influenced by other factors not examined in this study. The findings in this study indicate that the level of participation and application of the principles of good governance in social organizations such as in the LKSA Sejati Orphanage is easier than the implementation of good governance in government.

\section{CONCLUSION}

The level of participation in the LKSA Sejati Orphanage of Muhammadiyah Rappang, includes; planning, implementation, enjoying the results and evaluation activities have an average value of 85.5 percent included in the excellent category. The application of the principles of good governance in the LKSA Sejati Orphanage of Muhammadiyah Rappang, includes; accountability, transparency, openness and rule of law have an average value of 90 percent included in the excellent category. The participation of the LKSA Sejati Orphanage of Muhammadiyah Rappang to the application of the principles of good governance has a significant effect, in accordance with the results of the $r$ square value in the model summary table of 42.2 percent.

\section{REFERENCES}

Ahmad, J. (2015). Metode Penelitian Administrasi Publik Teori dan Aplikasi. Gava Media.

Cahya, A. A. (2016). Membangun Kampung Hijau Bersinar (Upaya Pendampingan dalam Membangun Kesadaran Masyarakat Kampung Kumuh di Bulak Banteng Lor I Kelurahan 
Bulak Banteng Kecamatan Kenjeran Surabaya). 31-50.

Digilib.Unila ( Unila ). (n.d.). Kajian Teori Good Governance (Universitas Lambung Mangkura). Retrieved from http://digilib.unila.ac.id/7273/16/BAB II.pdf

Fizriyani, W. (Harian R. (2017, November 21). Kemensos Target Tingkatkan Akreditasi 2.000 LKSA. pp. 10-11. Retrieved from https://nasional.republika.co.id/berita/nasional/umum/17/11/21/ozr0tf335-kemensostarget-tingkatkan-akreditasi-2000-lksa

Ilham Arisaputra, M. (2013). Penerapan Prinsip-Prinsip Good Governance Dalam Penyelenggaraan Reforma Agraria Di Indonesia. Yuridika, 28(2), 188-216. https://doi.org/10.20473/ydk.v28i2.1881

Laily, E. I. N. (2015). Partisipasi Masysrakat dalam Perencanaan Pembangunan Partisipatif. Kebijakan Dan Manajemen Publik, 3(3), 299-303. Retrieved from http://journal.unair.ac.id/filerPDF/kmpe7137ee51bfull.pdf

Muhammadiyah, P. A. S. (LKSA P. R. (2019). Laporan kegiatan dan sapras. RappangSidenreng Rappang-sulsel.

Purwanto. (2017). Metode Penelitian Kuantitatif Untuk Administrasi Publik dan masalahmasalah Sosial. 2017: Gava Media.

Razak, M. R. R. (2018). Terhadap Perwujudan Good Governance. Akmen Jurnal Ilmiah, 15(3), 476-496. Retrieved from https://e-jurnal.stienobel-indonesia.ac.id/index.php/akmen

Sugiyono. (2017). MetodePenelitian Administrasi. Publik. Bandung: CV. Alfabeta.

Wijayanti, R. (Universitas D., Rengga, A. (Universitas D., \& Santoso, R. S. (Universitas D. (2015). Implementasi Standar Pelayanan Berbasis Lembaga Kesejahteraan Sosial Anak (LKSA) Oleh Dinas Sosial, Pemuda dan Olah Raga Kota Semarang. Ejournal3 Undip. Retrieved from https://ejournal3.undip.ac.id/index.php/jppmr/article/download/8251/8020

Zuhro, R. S. (2016). Good Governance Dan Reformasi Birokrasi Di Indonesia. Ejournal Lipi. Retrieved from http://ejournal.lipi.go.id/index.php/jppol/article/download/507/316 
354 Jurnal Ilmiah Ilmu Administrasi Publik: Jurnal Pemikiran dan Penelitian Administrasi Publik Volume 9 Number 2, July- December 2019. Page 345-354 